\title{
Controversies in Political Ideologies: A Critical Discourse Analysis of Speeches of Indian and Pakistani Premiers on Pulwama Incident
}

\author{
Muhammad Imran Shah, ${ }^{1 *}$ Saeed Ahmad, ${ }^{2}$ Ali Danishs ${ }^{3}$ \\ 1, 2, 3 Department of Applied Linguistics, Government College University Faisalabad, Punjab \\ 38000, Pakistan \\ *) Corresponding Author \\ Email:m.imran.shah@gcuf.edu.pk \\ DOI: $10.18326 /$ rgt.v14i1.43-64
}

Submission Track:

Received: 10-07-2020

Final Revision: 01-04-2021

Available Online: 01-06-2021

Copyright (C) 2021 Authors

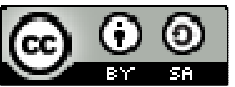

This work is licensed under a Creative Commons Attribution-ShareAlike 4.0 International License.

\begin{abstract}
Critical Discourse Analysis (CDA) is considered an effective approach to explore the hidden realities in a text. The current research analyzes the speeches of the leaders of the two states on the incident of Pulwama attack on 14th February 2019 in the region of Indian occupied Kashmir to control the minds of the audience and formulate their ideologies to achieve their political benefits through power abuse. The data has been taken from the speeches delivered by the both political leaders, the Premier of Pakistan Imran Khan and the Premier of India, Narendra Modi on Pulwama Attack. Both qualitative and quantitative research approaches have been followed to investigate the texts. For Quantitative data, AntConc 3.5.8 has been utilized for the frequencies and concordance of the important words to be discussed. Observation has been utilized to gain in-depth information to describe qualitatively. The results show that some specific linguistic choices regarding some specific vocabulary, pronouns, and modal verbs have been used ideologically by the premiers to manipulate the language of their speeches. The study will be important for researchers who want to investigate the discourse developed by the political leaders' speeches on same issue.
\end{abstract}

Keywords: discourse; pronoun; modality corpus; intertextuality 


\section{INTRODUCTION}

Politics is struggle for power to bring political, economic and social concepts into motion (Horvath, 2012). Language plays a crucial role in this process, since language is prepared, accompanied, inspired and played in any political action. This article endeavours to analyse the language used by two political leaders and the discourse they developed in their speeches on the same incident.

The context of the current research is a fatal attack on Indian troops in Pulwama that happened on February 14, 2019. Pulwama is a renowned city situated in the northern state of Indian occupied Jammu and Kashmir, $25 \mathrm{KM}$ from Srinagar, a strategic region in Kashmir vellay which has remained a bone of contention between India and Pakistan since the independence of the both states. Pakistan claimed the annexation of Kashmir based on religios, geographical and cultural ties whereas India occupied the region forcefully.

On 14th February 2019, the deadliest attack on Indian security forces was made when a group of 78 vehicles carrying more than 2500 CRPF (Central Reserve Police Force) soldiers was traveling on National Highway from Jammu to Srinagar. One bus of these vehicles carrying soldiers was hit by a fast running car carrying explosives at Lethpora which caused a heavy blast of a bus in which 40 CRPF soldiers were killed and many of them injured. The Freedom Fighter group "Jaish-e-Muhammad" took the responsibility of the attack which was made by a young Kashmiri boy, Adil Ahmad Dar who joined the group one year before. Indian Government immediately blamed Pakistan for this terrorist attack but Pakistan denied any responsibility for this attack or any involvement in this attack.

The statesmen from both the countries, Pakistan and India, reacted to this incident differently in their speeches. The researcher selected these speeches to be analyzed to find out the ideologies behind the linguistic choices of the speakers.

Correspondingly, to study the ideologies and the relationship of language, discourse and power, the researcher took Norman Fairclough's $(1989,1995)$ CDA framework for the current research. At the first stage of this framework i.e. at the structural level of analysis and power relations behind these choices. The 
main focus of the research was on some specific vocabulary items, pronominal choice and modal verbs at the structural level of analysis.

Audin (2019) conducted a study on the discourse analysis on Economic plenary debates over the general appropriations bill in the Philippines using Bramley's (2001) framework. His study focused on the personal pronouns in the text of debates. This study gave the basis to my research for the study of Pronominal choices in political debates or speeches. Allen (2007) advocates the fact that politicians try to present themselves as they can recognize and understand the needs, desires and interests of the general public or audience. They struggle to show themselves in a manner to have appeared as able and good leaders to the country or able politicians. Ghilzai, Ayaz, \& Asghar (2017); Khalil, Islam, Chattha, \& Qazalbash (2017); Shah (2018) have conducted researches on the speeches delivered by Imran Khan before and after premiership. All the researchers have found the ideological representation of linguistic impressions used in the language of the speeches using Fairclough's three-dimensional model. They have analyzed the speeches both at a structural and social level to find the power relations within the discourse and behind the discourse. But no research has been done to find the controversies in political ideologies through the language of the speeches of Indian and Pakistani premiers Narender Modi and Imran Khan. So this study fills this research gap in the field of Critical discourse Analysis.

The study aims to find out the most frequent linguistic items concerning pronouns, lexical choice and modality in the speeches of the premiers of India and Pakistan and to describe the functions of these linguistic items in the speeches.

Pertaining to this, Fairclough $(1989,1995)$ has proposed the most comprehensive model of CDA whose theory draws on Functional Grammar and recent social theories (Zhang, 2013). Moreover, he proposed a framework for CDA consisting of three layers which will be discussed in detail in next section of this segment.

Fairclough was greatly influenced by the Systemic Functional Linguistic (SFL) theory developed by Halliday (1985) after which he developed a threelayer CDA framework. This framework aims to explore the "exploitative social relations, through focusing upon language" (Fairclough, 1989, p. 4). Fairclough 
(1992, 1998) claims that language is used as social practice because it is an essential part of the various social actions and activities, variations and directions in the economic, political, ideological, and cultural areas of life.

Fairclough's Analytical Framework has the following three dimensions: 1) Text or Description of the text (The Micro level of Analysis): this level is related to the linguistic proprieties of the text e.g. news report or any piece of discourse. 2) Discourse practice or interpretation (The Meso-level of Analysis): This level deals with the correlation of text and interaction e.g. the process of production and consumption. 3) Socio-cultural practice or explanation (The Macro level of Analysis): this level is the correlation of interaction and social-context e.g. to analyze social and cultural structures which give rise to a communicative event (Fairclough, 1995b; Shakoury, 2018).

\section{Figure 1}

Fairclough's Three Dimensional Framework of CDA

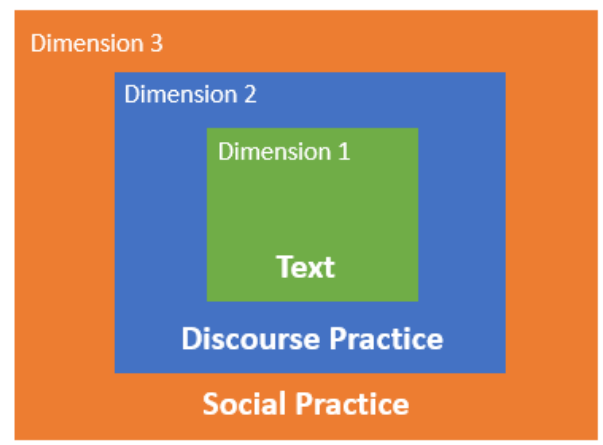

As the first dimension of Fairclough's framework, this level interprets discourse as text which includes the analysis of the linguistic features and expressions of text (Blommaert \& Bulcaen, 2000; Alhumaidi, 2013; Bazargani, 2015). This level of analysis studies the different linguistic expressions such as the selection of vocabulary, the use of metaphors, the various combination of words, grammatical structures such as the use of modality, passivize structures, and the use of transitive and intransitive expressions, cohesion as the utilization of different types of clauses and conjunctions and "text organization (e.g. episodic, turn-taking)” (Blommaert \& Bulcaen, 2000, p. 448). 
The second dimension of Fairclough's analytical framework known as meso-level of analysis includes the meso-level of analysis as the second dimension of the framework involves the theme of "text production, distribution, and consumption" and the investigation of their variability and the way it gets influenced by the social aspects (Fairclough 1992, p. 78). The main focus of this level is on "speech acts, coherence and intertextuality" (Blommaert \& Bulcaen, 2000, p. 448). At this level, main focus is on the study of the relationship of text (grammar, text structure, vocabulary and cohesion) and its context it is produced in, which is called intertextuality (North, 2014).

It is the third dimension of Fairclough's analytical framework for CDA which takes discourse as a socio-cultural practice (Fairclough, 1998, p. 311). At this dimension, the main focus of the analysis is to "three aspects of the sociocultural context of a communicative event: political (i.e. power and ideology of the media), economic (i.e. economy of the media) and cultural (i.e. issues of values)" (Sheyholislami, n. d., p. 9).

It is not necessary to analyze all the three dimensions of this framework. But the analytical research can be conducted at the level which is appropriate for the appreciation and comprehension of the specific text and according to the aim of the research (Fairclough, 1998). Thus the current study is mainly focused on this analytical framework. The analysis will be made on the first dimension of this framework.

Many researchers have investigated the political discourse developed by the politicians. Ramadhan and Listiyanto, (2017) conducted research based on the CDA of the speech which was delivered by the new elected president of United States of America (USA), Donald John Trump after his victory in the presidential elections in 2016. The researchers found that Trump used language tactically to persuade the people especially the people of the USA. For this research, the three-dimensional analysis was used to study the discourse which was practiced by the politician. This study was limited to only one speech given by US President Donald Trump. This study will be useful for my study in respect with its aims and goal, its methodology and data collection as the data will be collected for my research from the two leading leaders of the two states opposite to each other based on religion, culture, social norms and rules and historical aspects. 
Shah \& Noreen, (2018) also conducted research that analyzed the first speech of Imran Khan delivered by him as the Prime Minister (PM) of Pakistan after the general election (2018). They applied the three-layered analytical approach of CDA proposed by Norman Fairclough. The researchers analyzed the speech at the textual level, discourse-level and socio-cultural level. This study was based on the concept of Us versus Them through which Imran Khan made the picture of previous government negatively and himself in a positive way. This research will give a comparative basis to my research which hasl investigated the way how the political leaders of the two opposite states have represented themselves and the others.

Shakoury, (2018) has conducted a comparative research study (thesis) based on a CDA of eight speeches of two Iranian Presidents, Hassan Rouhani and Mahmoud Ahmadinejad, delivered to the United Nations General Assembly (2007-2016). Utilizing the 25 discursive devices introduced by Van Dijk (2005), the researcher has analyzed the linguistic features used in the speeches at a micro-level study of the text as well as at macro level study which focuses on the positive self-representation and negative the other representation. The results of his study show that President Rouhani has used the discursive devices 'consensus', 'illustration', 'hyperbole' and 'polarization' more excessively whereas President Ahmadinejad has made more use of lexicalization' and 'vagueness'. While at macro level, the comparative study of the speeches elaborates Rouhani utilizes 'positive self-representation' and Ahmadinejad relies on 'negative other-representation'. It has also been found out from the study that both the presidents have shown different points of view on most of the topics although, on some topics like 'world Zionism and the occupation of Palestine', their ideological views are quite similar.

The previous studies have given insight for the research methodology, data collection, and data analysis tools.

\section{RESEARCH METHOD}

To achieve the purpose of research, the data was taken from the speeches delivered by two leading political leaders and heads of the two states, the Prime Minister of Pakistan Imran Khan (three speeches delivered on February 19, 27 and 28, 2019) and the Prime Minister of India, Narendra Modi (five speeches 
delivered on February 15, 16, 24 and 26 February 2019) on Pulwama Attack. The data has been taken in the form of videos downloaded from YouTube and then transcribed and translated in English using Google Translator and manually. The speeches have been taken because the two personalities are leading politicians of Pakistan and India and are the Premiers, the representatives of both the states.

For this research study, the researcher compiled a corpus consist of five speeches of the premier of India and three speeches of the Premier of Pakistan. To answer the research questions both qualitative and quantitative methods have been used. To find the frequencies and concordance of the lexical choices such as pronoun, modal verbs, a powerful corpus software AntConc 3.5.8 (2019) was used. Its tools of the word list, concordance and file view were used to draw the frequencies and to see the most frequently used lexical choices in the context of the speech. For the further descriptive study of the speeches based on the frequencies of the linguistic items, the personal identification was used as a tool of qualitative research.

\section{Data Analysis}

For this research, the researcher selected five speeches of the premier of India and three speeches of the Premier of Pakistan. These speeches have been analyzed critically to investigate how the two premiers have used language on Pulwama incident to show their hidden motifs, intentions and ideologies. The thorough analysis of the speeches shows how the premiers have manipulated language through their tactful choice of linguistic choice. At the first stage of Fairclough's analytical framework, the text of speeches has been analyzed on a linguistic basis as text is considered the basic pillar of Fairclough's CDA analytical model. The speeches of both Premiers have been analyzed separately to find out the controversies of the ideologies hidden in their language of speeches. The speeches of Imran Khan the Premier of Pakistan consist of 3940 words and that of Premier of India Narendra Modi consist of 4467 words. The speeches include many linguistic features that have been discussed in the following segments.

Lexical items of any text play a vital role in the production and interpretation of the linguistic features of that text. Vocabulary is laden with ideologies of the speakers or the writers which can be explored through 
analysis of that vocabulary items. The thorough analysis of vocabulary explores some particular ideologies. In so for as the present text of the speeches is concerned, so many words are used in this text which is ideologically contested. The use of Islamic terms in the form of "In the Name of Allah the Most Beneficent, the Most Merciful" shows his Islamic ideology. Religion is considered the most powerful ideological element in any society. That is why the Khan has started his speech with the name of Allah to show his keen love for his religion.

The words peace and dialogue have been used 9 times both in the speeches of Pakistani Premier. The critical analysis of the usage of these two lexical items in the speeches of Pakistani Premier shows his desire and urge for peace in the subcontinent which can come only through dialogues between the two countries. He shows his willingness for the dialogues with India and is ready for solving all the issues. He warns the consequences of the war and gives the example of Afghanistan and America conflict which is going to be solved through dialogues which throws light on the importance of dialogues. As in the following chunks from speeches of Pakistani Premier, Imran Khan, is shown.

"Terrorism is on the decline; Peace is on the horizon..."

"We offered peace to India after what happened in Pulwama..."

"we are ready for dialogue on terrorism..."

"If it (America) has come on dialogue today, the war is not the solution of problems..."

On the other hand, the lexical item "peace" has occurred only two times and "dialogue" has not occurred in all the speeches of Indian Premier, Narendra Modi. He has not shown his decline to peace or the solution through dialogue. The usage of these lexical items shows that Pakistan wants peace instead of warlike situation while Indian Premier has avoided these words which elaborates his negative attitude towards peace in the subcontinent.

The use of pronouns has relational value in any text or talk. The use of ' $\mathrm{I}$ ' and 'we' refer to the speaker or writer, their addressees or readers and 'you' has also a relational value. The pronoun 'you' refers to the addressees or the listeners. The use of pronouns is not made unconsciously especially in the writing or speech in front of public or common masses. Most of the time they use of some particular pronouns is a conscious effort of the writer or speaker 
when he/she is to convey some message through his/her language to impose his/her ideologies to the audience to get cognitive control.

In the speeches of the two premiers, some pronouns have been used in different ways. The following table shows the use of these pronouns with their frequencies.

\section{Table 1}

Use of Some Specific Personal Pronouns and Their Frequency

\begin{tabular}{llllll}
\hline \multicolumn{2}{l}{$\begin{array}{l}\text { Pronouns in Imran Khan's Speeches } \\
\text { (Total Words 3940) }\end{array}$} & \multicolumn{3}{l}{$\begin{array}{l}\text { Pronouns in Narendra Modi's } \\
\text { Speeches (Total Words }\end{array}$} \\
\hline Pronoun & Frequency & $\%$ & Pronoun & Frequency & $\%$ \\
\hline We & 103 & 2.61 & I & 71 & 1.59 \\
I & 74 & 1.88 & We & 34 & 0.76 \\
You & 32 & 0.81 & You & 38 & 0.85 \\
\hline
\end{tabular}

Premier of Pakistan, Imran Khan has used the first person 'we' more than 'I' in his speeches which show his collective nature of working which is a useful technique to formulate the opinion of the general masses. Here the pronoun 'we' refers to the whole nation of Pakistan and the government of Pakistan.

It was found that most of the verbs used with the pronoun 'we' were action verbs like 'have signed', 'conveyed', 'are doing', 'are trying', 'decided' and so on. All these verbs show that Pakistani Premier is confident with his nation and government. He as well as his government is acting. The action verbs show that the Pakistani nation is united and government and the general masses are working on one platform and they are ready for every action collectively as Figure 1 shows. Imran Khan has used a variety of linguistic expressions with the pronoun 'we' as 'we are afraid, that we have any panic', this expression shows Khan's worry about his country in the context of Pulwama Incident. Present progressive expressions show his active nature that many activities are in progress. The addressee of the Khan's speech is India and for India, Khan has a clear message in the following expressions: 'we are ready to talk about terrorism', 'we are ready to talk to you', 'we are ready. If you have any 
actionable intelligence'. Here the pronoun clearly defines that the whole Pakistani nation is united on the issue of terrorism.

On the other hand, Indian Premier Narendra Modi has used the first person pronoun 'I' more than 'we' which shows his self-confidential nature. The research shows that in Modi's speeches modal verbs have been used more than action verbs. Figure 2 shows that he has used future tense with model 'will' for 6 times with 'we': '... will cut of our heads..., '... will fight against poverty..., 'will fulfill whatever you say...', 'will leave no stone unturned to fulfill their dreams for...', 'will not break the promise...', 'will strive hard to gather...'. All these sentences show his plans and his useful technique of impressing his audience. Modi has used two times the attribute expression with 'we are': 'in a state of grief, 'one nation'. He has used these linguistic expressions consciously to impress the audience by showing his sympathies with the families of the soldiers who were killed in Pulwama Incident.

\section{Figure 2}

The Concordance of the use of Pronoun 'We' in Imran Khan's Speeches

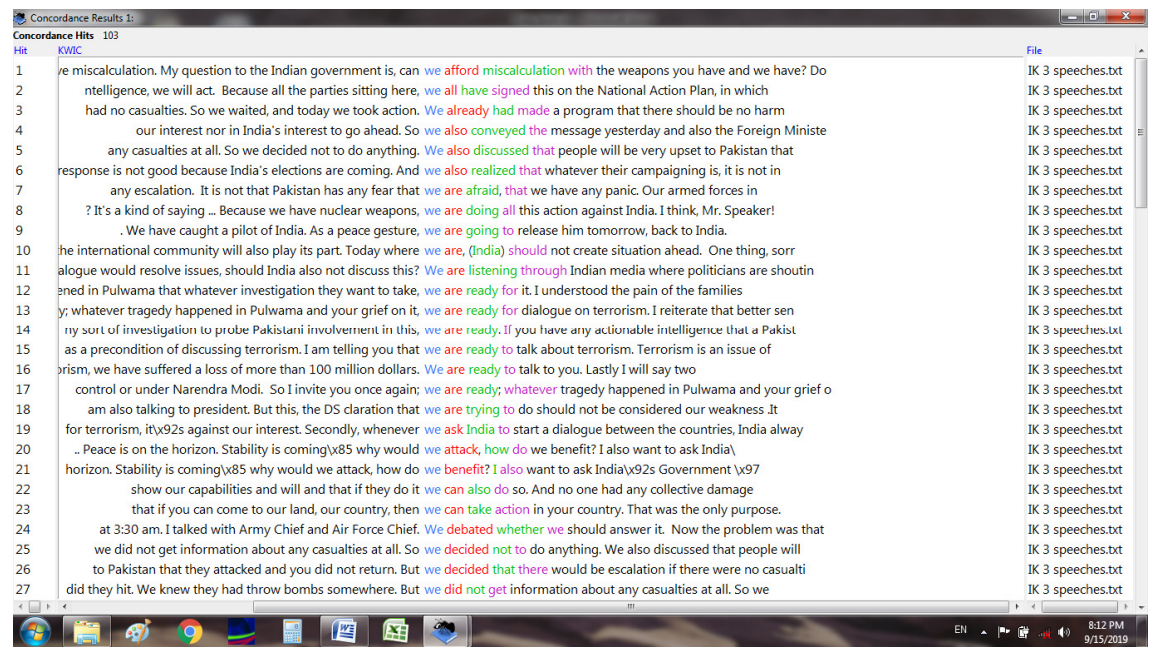

The research shows that both the premiers of India and Pakistan have used the pronoun 'we' very tactfully to show their sincerity for the general masses as well the government. Using this technique, they have tried to capture the minds of audiences to manipulate their ideologies and to get their support 
for their stance which is hidden in their speeches. So, the research shows that power has been abused through the tactful use of first-person pronouns. The table also shows that Imran Khan has used first-person pronouns more than Modi has used in the speeches which shows Imran Khan's keen attachment with his country and nation.

The research shows that the addressees of Modi are the people of his country i.e. general masses, media, and his opponent political parties. He has used the pronoun 'you' very tactfully to control the minds of people of his country to manipulate his ideologies, motifs and political aims. The table 4.1 shows that the pronoun 'you' has been used by Modi more than Imran Khan with a percentage of $0.85 \%$ and $0.81 \%$ respectively. This shows that Modi has the main focus on his audiences and uses language consciously to attract the attention of his audience. It has been suggested that 'you' is not used forever to analyse practical experience; rather it is used to discuss 'conventional wisdom' instead. In this way, 'you' is used to articulate common sense or truth commonly admitted, with the hope of offering the audience's agreement (Allen, 2007).

\section{Figure 3}

The Concordance of the Use of Pronoun 'We' in Modi's Speeches

\begin{tabular}{|c|c|c|}
\hline \multicolumn{3}{|c|}{$\begin{array}{l}\text { Concordance Hits } 34 \\
\text { Hit }\end{array}$} \\
\hline 8 & e fight against terrorism. Friends, after Pulwama terror attack, we are in a state of grief as well as deep anger. & Modi 5 speeches.txt \\
\hline 9 & will be so. Today, terrorism has become a frightening scenario. We are moving forward firmly on every front to punish terrorist cri & Modi 5 speeches.txt \\
\hline 10 & politics. The message which should go across the world is that we are one nation, one voice in our fight against terror, the & Modi 5 speeches.txt \\
\hline 11 & people will provide correct information to our agencies so that we can intensify our efforts to crush terror. I want to tell & Modi 5 speeches.txt \\
\hline 12 & dia. This pain will not be tolerated by the government silently. We cannot keep quiet because of this pain. We also know how & Modi 5 speeches.txt \\
\hline 13 & down their lives for the sake of their country, so that we could live, so that the country could be safe \& secure, paving & Modi 5 speeches.txt \\
\hline 14 & took a resolve that the country must have such a Memorial. We decided to erect the National War Memorial and I am contented & Modi 5 speeches.txt \\
\hline 15 & y have followed they have destroyed themselves. The course which we have adopted is one of progress and development. 130 crore India & Modi 5 speeches.txt \\
\hline 16 & path you have adopted, You have seen your ruin. The path we have adopted, our day doubled, the night progressed four times, & Modi 5 speeches.txt \\
\hline 17 & ite natural. We have given full freedom to the security forces. We have full faith in the bravery and valour of our security & Modi 5 speeches.txt \\
\hline 18 & Rajisthan who are full of anger about some government policies. We have given army the free hand (of taking any action). And & Modi 5 speeches.txt \\
\hline 19 & and the feelings of a strong response which is quite natural. We have given full freedom to the security forces. We have full & Modi 5 speeches.txt \\
\hline 20 & . He too is ready to come with us to end terrorism. We have to keep him together. You may have seen that millions & Modi 5 speeches.txt \\
\hline 21 & nation, one voice in our fighth aydinst terror, the fighth whicht we have to wint. Out neightbuur which is already isulated by the & Mudi 5 speeches.lst \\
\hline 22 & time. Tomorrow, that is on the 25th of February, crores of we Indians will dedicate this National Soldiers $\times 92$ Memorial to our & Modi 5 speeches.txt \\
\hline 23 & and sisters! If we want to win the fight by mistake, we must eradicate the roots of terrorism. Kashmiri is still sufferi & Modi 5 speeches.txt \\
\hline 24 & uproot the very base of terrorism; it will fortify our resolve. We shall have to take up this challenge facing our country, forgett & Modi 5 speeches.txt \\
\hline 25 & moment and the nation stands united in its fight against terror. We should speak in one voice and rise above politics. The message & Modi 5 speeches.txt \\
\hline 26 & been allowed to be bum. Therefore, my brothers and sisters! If we want to win the fight by mistake, we must eradicate the & Modi 5 speeches.txt \\
\hline 27 & . Then my brothers of Kashmir Valley said, Modiji you say, we will cut off our head but we will not break the & Modi 5 speeches.txt \\
\hline 28 & ou came from the sports world. Come together India and Pakistan, we will fight against poverty, fight against $\times 93$ Asakshalx94, fight & Modi 5 speeches.txt \\
\hline 29 & I said but you have not heard what I ask for. We will fulfill whatever you say. And this is the first time & Modi 5 speeches.txt \\
\hline 30 & . I salute our martyrs, seek their blessings and assure you that we will leave no stone unturned to fulfil their dreams for which & Modi 5 speeches.txt \\
\hline 31 & Modi ji you say, we will cut off our head but we will not break the promise. I said but you have not & Modi 5 speeches.txt \\
\hline 32 & for which they have laid down their lives for the nation. We will strive hard to gather momentum on the road to development & Modi 5 speeches.txt \\
\hline 33 & anches told me that after that, we would sacrifice ourselves but we would not let the terrorists burn schools. I told him when & Modi 5 speeches.txt \\
\hline 34 & in any case. All the sarpanches told me that after that, we would sacrifice ourselves but we would not let the terrorists bu & Modi 5 speeches.txt \\
\hline
\end{tabular}


Figure 4

The Concordance of the Use of Pronoun 'you' in Modi's Speeches

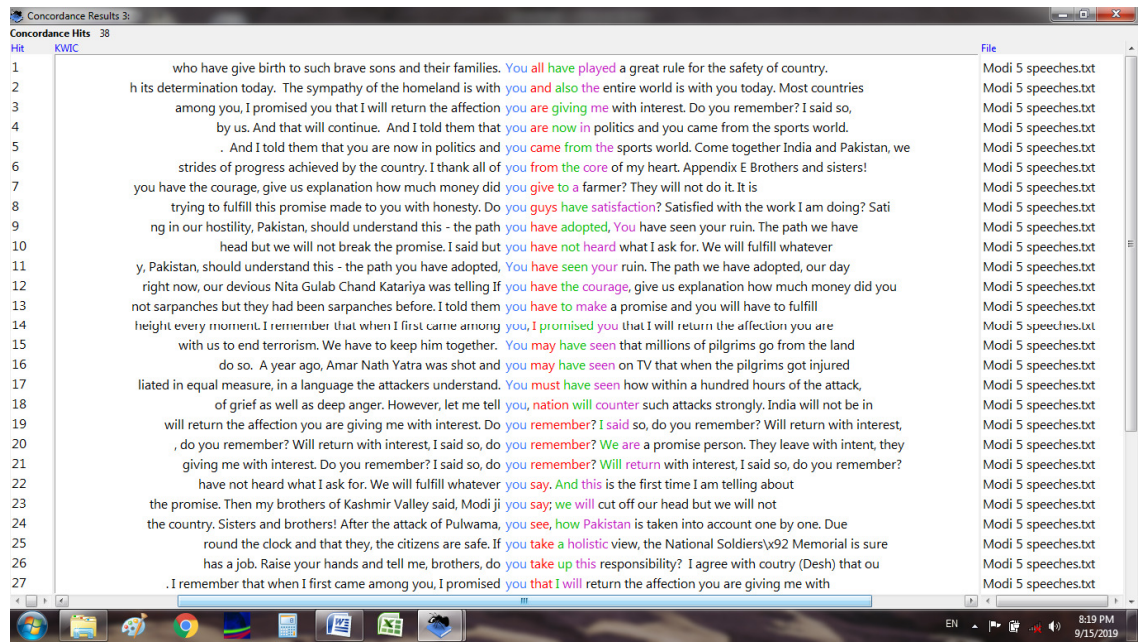

\section{Figure 5}

The Concordance of the Use of Pronoun 'you' in Imran Khan's Speeches

\begin{tabular}{|c|c|c|}
\hline \multicolumn{3}{|c|}{ Soncordance Results 4: } \\
\hline \multicolumn{2}{|c|}{$\begin{array}{l}\text { S Concordance Results s: } \\
\text { Concordance eits } 32 \\
\text { Ht KWMC }\end{array}$} & \\
\hline 6 & people will be very upset to Pakistan that they attacked and you did hot return. But we decided that there would be escalation & IK 3 speeches.t女t \\
\hline 7 & $s$ platform that not to take any further action. Because whatever you do, Pakistan will be forced to retaliate. And then two countries & IK 3 speeches.txt \\
\hline 8 & attack on its own country. But we repeatedly told them that you give us actionable intelligence. Now today, the Dossier of India & IK 3 speeches.txt \\
\hline 9 & not the solution of problems. And when this warming starts and you go towards escalation. For example, if India takes any action no & IK 3 speeches.txt \\
\hline 10 & ian government is, can we afford miscalculation with the weapons you have and we have? Do we not have to think right & IK 3 speeches.txt \\
\hline 11 & igation to probe Pakistani involvement in this, we are ready. If you have any actionable intelligence that a Pakistani was involved, & IK 3 speeches.tzt \\
\hline 12 & tmosphere. On one side, Pakistan was trying to cooperate India. You have been attacked and we help you if you tell us. & IK 3 speeches.txt \\
\hline 13 & to respond. This is a response for the Indian government. First, you have blamed Pakistan for the attack without any evidence, withou & IK 3 speeches.txt \\
\hline 14 & Instead of starting a dialogue to resolve the issue in Kashmir, you have made Pakistan the whipping boy. I have repeatedly said that & IK 3 speeches.txt \\
\hline 15 & trying to cooperate India. You have been attacked and we help you if you tell us. On the other hand, there is Pakistan- & IK 3 speeches.txt \\
\hline 16 & of more than 100 million dollars. We are ready to talk to you. Lastly I will say two things $x 96$ There should be a & IK 3 speeches.txt \\
\hline 17 & be under my control or under Narendra Modi. So I invite you once again; we are ready; whatever tragedy happened in Pulwama a & IK 3 speeches.txt \\
\hline 18 & as to how Pakistan would gain from it. Let me assure you, Pakistan derives no benefit from such acts - Even a foolish per & IK 3 speeches.txt \\
\hline 19 & cournthy ir which the Hero is Tapu Sullarn. A nation, when you push it up, arly nation, leave Pakistan, when you push it & IK 今 spetedies.lxt. \\
\hline 20 & nation, when you push it up, any nation, leave Pakistan, when you push it up to the stage where it has to decide, & IK 3 speeches.tKt \\
\hline 21 & all the disputes which he had with his neighbours. And if you see that during the past 15 years, when America was spending one & IK 3 speeches.tit \\
\hline 22 & taking action on its complaints anyway. So we told them that you should give us evidence and we will act Unfortunately, instead & IK 3 speeches.txt \\
\hline 23 & Id prevail. Let us sit together and settle our problems. Thank you so much. Appendix H $\times 93$ In the Name of Allaah the & IK 3 speeches.txt \\
\hline 24 & I told them that we would have to be compelled when you take action. We will be compelled to respond. Because no soverei & IK 3 speeches.txt \\
\hline 25 & cooperate India. You have been attacked and we help you if you tell us. On the other hand, there is Pakistan-Afghanistan issue. & IK 3 speeches.txt \\
\hline 26 & always has a precondition of discussing terrorism. I am telling you that we are ready to talk about terrorism. Terrorism is an & IK 3 speeches.txt \\
\hline 27 & orture and resolving issues through military is the solution? Do you think if it hasn $\times 92$ t worked till now, would it & IK 3 speeches.tKt \\
\hline 28 & x $92 t$ fear death anymore. There must be some reason. Do you think one-dimensional oppression, torture and resolving issues $t$ & IK 3 speeches.txt \\
\hline 29 & get a boost if Pakistan should be taught a lesson. If you think, you would launch any attack on Pakistan and we would & IK 3 speeches.txt \\
\hline 30 & something will happen in Pakistan. So I also conveyed that if you violate any action against Pakistan, we will answer it. And it & IK 3 speeches.txt \\
\hline 31 & It is your election year and we understand that during elections you will get a boost if Pakistan should be taught a lesson. & IK 3 speeches.txt \\
\hline 32 & boost if Pakistan should be taught a lesson. If you think, you would launch any attack on Pakistan and we would not think & IK 3 speeches.txt \\
\hline
\end{tabular}

On the other hand, Premier of Pakistan is clear in his stance. He has used the pronoun 'you' directly for India to response his comments for Pakistan on the Pulwama incident. He clearly conveys his message addressing the 
government of India directly in his speech. Most of usage of 'you' in his speeches has been made for Modi and his government which shows the boldness and clear point of view of Imran Khan.

Halliday (1994) claims that through the use of Modality, the degree of assurance, firmness or certainty of the viewpoint is expressed about the validation of their statements or are used to practice their command over the general masses. The modality is laden with deep ideological power to be practiced in the speeches. Modality is used to infuse an additional sound in the speeches and texts. Table 2 shows the distribution of the use of modality in the speeches of the two premiers.

Table 2

Modal Verbs

\begin{tabular}{llllll}
\hline \multicolumn{2}{l}{ Modal Verbs in Imran Khan's Speeches } & \multicolumn{3}{l}{ Modal Verbs in Modi's Speeches } \\
Modal Verbs & Frequencies & $\%$ & Modal Verbs & Frequencies & $\%$ \\
\hline Will & 39 & 0.99 & Will & 48 & 1.07 \\
Should & 29 & 0.73 & Should & 10 & 0.22 \\
Would & 27 & 0.68 & Would & 5 & 0.11 \\
Can & 5 & 0.13 & Can & 6 & 0.13 \\
Have to & 5 & 0.13 & Have to & 6 & 0.13 \\
Must & 1 & 0.03 & Must & 6 & 0.13 \\
May & 1 & 0.03 & May & 5 & 0.11 \\
\hline
\end{tabular}

The Table 2 shows that the most frequently used modals in the speeches of Imran Khan are "will", "should" and "would" while "will" is the only modal auxiliary verb which has been used by Narendra Modi in his speeches. The excessive use of the modal verb "will" by both the premiers shows their predictions of the future. The use of "will" shows what will happen in the future. The comparison between the usage of "will" shows that Indian Premier has made more excessive use of it than Pakistani Premier has made which shows his future predictions about his country and Pakistan. Some text has been taken from his speeches.

"Pakistan has found nothing. Every fight has won by us. And that will continue."

"we will fight against poverty"

"people of the country will come together and give a befitting reply to this plan, our neighbors." 
In the following lines taken from the speeches delivered by Indian Premier show his future plans which will be taken against terrorists. He has told that all the wars fought against Pakistan have been won by India, and Pakistan has gained nothing. He explicitly warns his neighbor country against terrorist attacks. His use of future intentions "we will fight against poverty" shows his political insight which all the politicians use just before the elections.

On the other hand, the statistical data in table 2 shows that Imran Khan has also used the modal verb to show his plans. The thorough analysis of his speeches shows that he is ready for any situation created by India. His first mission is to solve all the issues through dialogues. He has offered India to provide the logical information about the incident and Pakistan will take action.

"give that information to us. I guarantee that I will take action."

Here Imran Khan has used the modal auxiliary verb "will" with the personal pronoun "I" with his guarantee that he will take action. This line shows his willpower, his self-confidence in his power of taking action. Here he has shown his authoritative power to control the minds of the people especially to show his power of decision to India.

Imran Khan has also shown his opinion about the incident and intentions of the Bharatiya Janata Party getting political benefits from the incident.

"But we were afraid that there will be an event before the election, which will be exploited for the election."

"We understand that during elections you will get a boost if Pakistan should be taught a lesson."

These lines show the sensible nature of Pakistani Premier about Indian actions that they are using this incident for the election campaign to get control over the minds of the general masses to get the vote by punishing Pakistan.

In response to Indian Premier's allegations on Pakistan for Pulwama Incident and his threats against Pakistan, Pakistani Premier has made it clear in an explicit way as a responsible head of the state that if India takes any action, Pakistan will retaliate. Here the auxiliary modal verb is used conditionally. It shows that Pakistan does not want any war-like situation but in his defense, Pakistan will not spend his time in thinking but will retaliate. It shows Pakistani Premier's strong will power and his spirit of patriotism. 
"If you think, you would launch any attack on Pakistan and we would not think of retaliating, Pakistan will retaliate." "We will be compelled to respond."

The following lines show that Pakistani Premier wants peace and he has offered for peaceful situation. He has stressed to use minds before creating any situation. He hopes for the betterness in the future.

"I hope better sense will prevail, we will use our intelligence and wisdom."

He has shown his ideological views about a peaceful situation to India by saying, "if India moves one step towards Pakistan, we will take two steps towards them." Which shows Pakistan's readiness for the solutions through dialogue. This line clearly shows Pakistan's open-hearted nature for India.

Pakistani Premier has conveyed another message to his audiences that the Pakistani government will never let his soul to be used for terrorism. Here the Premier has used the modal auxiliary verb "will" with the personal pronoun "we" as an inclusive pronoun which means that "we" includes the government as well the people of Pakistan and some of his audience except India. By saying,

"We have decided that we will not allow any kind of terrorism inside Pakistan."

"Pakistan will never allow its soil to be used for terrorism."

He has shown his spirit of patriotism to convey his patriotic ideology to the audience to get control over their minds.

The thorough critical analysis of the speech have also shown the Pakistani Premier's keen and deep interest in the Kashmir issue. He has made his future predictions about the Kashmiri people. He has warned India that their oppression on Kashmiris will create chaos. He has used "will" in the form of the interrogative sentence to lay stress on the importance of the issue. He has offered India to solve the issue through dialogues otherwise if India continues the same situation, such terrorism will be made. Through future predictions, Imran Khan has shown his ideology using Future tense. He has not used the future tense unintentionally rather he has used it consciously which shows his consciousness about the situation which may be created in the future.

"Will they subdue Kashmir and the people of Kashmir through these tactics, such oppression and cruelty?"

"Kashmir requires debate that what will be about Kashmir next? If this situation persists, I am afraid there will be reaction which will result such 
terrorism. Will the fingers again be lifted on Pakistan? And so on, will Pakistan be called at once to take action, without giving any evidence?"

Kashmir issue has been acknowledged internationally for decades. Pulwama incident is also related to this issue after which Pakistan was blamed for the responsibility of this incident. Pakistani Premier has made predictions that if the same situation is continued, some incident may be happened and again Pakistan will be blamed for it.

The auxiliary modal verb "should" is used to show moral obligation of the speaker or writer. It shows the speaker's or writer's moral sense and point of view for the activities. The auxiliary modal verb "should" have been used more excessively by Imran Khan than Narendra Modi which shows Imran Khan's politeness for his audience. The critical analysis of the speeches of both the Premiers shows that "should" has been used by an Indian premier in some strict manners. He has used it for the strong obligation to take actions against terrorists which has been shown in the following lines.

We should speak in one voice and rise above politics.

Here he has stressed for the unity of the whole country against the terrorists. Yet in the following lines, he has shown his hatred against Pakistan considering him a terrorist country. The thorough analysis of his speech regarding to the use of "should", shows his mentality of getting the favour of the audience against Pakistan to get his political purposes. Pakistan and India are two opposite countries in their religious beliefs and critics consider religion the most powerful and sensitive ideology. To gain his political benefits for the election campaign, Narendra Modi has touched the very sensitive ideology of the people, religious ideology to arose their hatred against Pakistan.

"Our neighbour which is already isolated by the global community is in a state of illusion, if it thinks that it can demoralize India with its dastardly acts and nefarious designs. Let me state categorically that it should stop day dreaming to destabilize India".

The investigation of the utilization of the model auxiliary by Pakistani Premier is more interesting as he has used this modal verb than Indian Premier.

"I should have responded immediately as Pakistan was blamed for it".

This line shows his sense of responsibility as premier of Pakistan to respond to India because they blamed Pakistan for an attack in Pulwama. As 
head of the state, he considers himself responsible for the response as he has used the First-person pronoun "I" with the obligatory modal verb "should".

\section{RESULTS AND DISCUSSION}

The results show great differences in the ideologies of the Premiers. Firstperson pronouns "I" and "we" have been used by both the premiers in their speeches. The analysis of the use of these pronouns shows their collective nature of working but in Imran Khan's speeches "we" is used more frequently while Modi's speeches "I" have been used more frequently. This shows that Imran Khan has more confidence in his government and the people of his country than in himself. On the other hand, Modi has more confidence in himself than his government. Most of his actions are controlled by the personal pronoun "I". This shows that both the Premiers have consciously used pronomial clause to exhibit their intentions.

The use of the second-person pronoun "you" has been used both the Premiers with the almost same percentage. But the analysis of the speeches has shown that the function of you is different in the speeches of the premiers. "You" refers to the audience for any spoken or written discourse. In Modi's speeches, the addressees are the people of his country. So he has made the use of these words to convince the people of his country to get support for his actions. On the other hand, the addressee of Imran Khan is the government of India. He directly addresses the Indian government on the issue of the Pulwama attack. Most of the use of the word "you" has been as the receiver of offers made by Imran Khan for dialogues and offering full support for any investigation about this attack. While Narendra Modi has shown strict ideology for Pakistan to his audience.

The analysis of modality in the speeches shows interesting results. The use of model auxiliary "will" shows the plans of the speaker or the writer. A thorough analysis of the utility of this modal verb has uncovered the hidden ideology of both premiers. Narendra Modi's future plans are based on the warning to Pakistan he has shown his negative ideology against Pakistan. He rest the responsibility of the fatal attack on Pakistan without any solid evidence. He has not given even a single clue for the peace gesture or offering or accepting the solutions the issue through dialogue which Imran Khan has offered several 
times in his speeches. The investigation of the words "peace" and "dialogue" shows the controversies in the political ideologies of the Indian and Pakistani political leaders. One is demonstrating patience and the other is impatient and promoting war and instability in the region.

\section{CONCLUSION}

The paper has suggested, inorder to analyze the political speeches of statesmen, the indepth study of the contextual use of lexicon, pronouns and the model auxiliaries used by the speakers is necessary. The speeches of the premiers of Pakistan and India on the Pulwama incident have been analyzed. This study is based on textual as well as contextual analysis with reference of the use of pronouns, vocabulary items and modality in the speeches. The frequency of the personal personal pronouns with the fuctional verbs exhibited the mentenality of the speakers; how they tried to generate the ideology and controle the general mases. The contextual use of model auxiliaries showed their intentions which would exlpicity differentiale the amiable nature of Imran Khan and the aggressive intentions Narendra Modi.

Further studies can be made on the speeches of other politicians using this methodology. These speeches can also be investigated using Van Dijk's theory of socio-cognitive theory and his concept of "positive self-representation and other negative representation. Speeches in the Pakistan National Assembly can be analyzed using this same methodology. This research will be useful for the coming students of research. It can also be supportive for the analysis of speeches that how the politicians manipulate language and controle the mind of general public before the elections. The study will also helpful to analyze the discourse on different issues which are contentious among the nations. The speeches of Imran Khan and Narendra Modi in the UN Assembly can also be critically analyze using Fairclough's model of CDA.

Moreover, the study has stronge pedagogical implications as both teachers and learners can use the same practical strategy for the textual analysis of the political speeches to expose the hidden ideologies of the language user. Teachers can envolve the students to do textual analysis for the enhancement of procedural knowledge following the inductive learning stretagy.[rgt] 


\section{REFERENCES}

Alhumaidi, M. (2013). A critical discourse analysis of Al-Ahram and Aljazeera's online coverage of Egypt's revolution (Doctoral dissertation). University of Florida.

Allen, W. (2007). Australian political discourse: Pronominal choice in campaign speeches. In M. L. Mushin. (Ed.), Conference of the Australian Linguistic Society. (pp. 1-13).

Anthony, L. (2019). AntConc (Version 3.5.8) [Computer Software]. Tokyo, Japan: Waseda University. retrieved from https://www.laurenceanthony. net/software

Audin, A. G. (2019). A Discourse Analysis on Economic Plenary Debates over the General Appropriations Bill in the Philippines. Asian EFL Journal Research Articles, 23(3.4).

Bayram, F. (2010). Ideology and political discourse: A critical discourse analysis of erdogan's political speech. Annual Review of Education, Communication \& Language Sciences, 7.

Bazargani, D. T. (2015). A comparative study on two translations of the Holy Qur'an: A critical discourse analysis approach. Translation studies, 13(49), 49-64.

Blommaert, J., \& Bulaen, C. (2000). Critical discourse analysis. Annual Review of Anthropology, 29, 447-66.

Bramley, N. R. (2001). Pronouns of politics: the use of pronouns in the construction of 'self and 'other' in political interviews. Retrieved from: https://openresearch-repository.anu.edu.au/handle/1885/46225

Brown, G., \& Yule, G. (1983). Discourse analysis. Cambridge University Press.

Devereux, E. (1998). Devils and angels: Television, ideology and the coverage of poverty. University of Luton Press.

Fairclough, N. (1989). Language and power. Longman.

Fairclough, N. (1992). Discourse and social change. Polity Press

Fairclough, N. (1995). Critical discourse analysis.. Longman.

Fairclough, N. (20/12/2006). Tony Blair and the language of politics. Retrieved from: http://www.opendemocracy.net/democracy-blair/blair_language_ 4205.jsp (Accessed: 24 July 2017). 
Fairclough, N. (2013). Critical discourse analysis: The critical study of language. Routledge.

Foucault, M., \& Deleuze, G. (1977). Intellectuals and power: Language, countermemory, practice: Selected essays and interviews, 205, 209. Cornell University Press

Fowler, R. (1986). Linguistic criticism. Oxford University Press.

Fowler, Roger. (1991). Language in the news: Discourse and ideology in the press (Vol. 20). Routledge.

Garfinkel, H. (1967). Studies in ethnomethodology. Polity Press.

Gee, J. P. (1991). A linguistic approach to narrative. Journal of Narrative and Life History/Narrative Inquiry, 1(1), 15-39.

Ghilzai, S., Ayaz, M., \& Asghar. (2017). A Critical Discourse Analysis of Imran Khan's First Speech in the Parliament Perspectives in Language, Linguistics and Media 2 (2017) 149-167.

Halliday, A. K. (1985). An introduction to functional grammar (2nd ed.). Edward Arnold.

Horvath, J. (2012) Critical discourse analysis of obama's political discourse, retrieved from: http://www.cs.columbia.edu/ sbenus/Teaching/APTD/Horvath_CDO_Obama.pdf

Johnstone, B. (2008). Discourse analysis. (2nd ed.). Blackwell Publishing.

Khalil, U., Islam, M., Chattha, S. A., \& Qazalbash, F. (2017). Persuasion and political discourse: A critical discourse analysis of Imran Khan's election speech (2013). Pakistan Vision, 18(2), 193-210.

Kress, G. (Ed.). (1976). Halliday: System and function in language. Oxford University Press.

Malimas, M.A, Carreon, J.A., \& Peña, N.W. (2018). Critical discourse analysis of filipino women politicians' campaign speeches. The Asian EFL Journal, 20 (12.2), 386-401.

North, H. (2014). The discourse analysis of united states foreign policy towards Iraq and Egypt (Master's thesis). Masaryk University.

Post, M. D. (2009). Representations of meaning within textual personas: An analysis of 2008 US presidential campaign speeches (Master's thesis). University of Birmingham. 
Sajjad, F. (2015). A critical discourse analysis of Barack Hussein Obama's political speeches on the Middle East and the Muslim World. International Journal of Linguistics, 7(1), 1-41.

Shah, M. I., A. Noreen (2018). A critical discourse analysis of Prime Minister of Pakistan Imran Khan's first public address. International Journal of English Linguistics, 8 (9), 1-6.

Shakoury, K. (2018). Critical discourse analysis of Iranian Presidents' Addresses to the United Nations General Assembly (2007-2016). University of Saskatchewan.

van Dijk, T. A. (1988). News as discourse. Lawrence Erlbaum Associates.

Van Dijk, T. A. (1998). Ideology. Sage Publications Ltd.

Van Dijk, T. A. (2008). Discourse and power. Macmillan International Higher Education.

Wiggins, S. (2009). Discourse analysis. In Encyclopedia of Human Relationships. Sage Publications (pp. 427-430).

Zhang, X. (2013). The third US-China strategic and economic dialogue: A contrastive study of Chinese and American Newspaper News Reporting. University of Florida. 
The page has been intentionally left blank. 